\title{
Developing effective and efficient study specific training to enable rapid study start up
}

\author{
Lynda Constable*, Alison McDonald, Cathryn Glazener \\ From 2nd Clinical Trials Methodology Conference: Methodology Matters \\ Edinburgh, UK. 18-19 November 2013
}

Study specific training is an essential but often understated component of the study set up process for individual site personnel. One of the many challenges for the trial manager is to ensure study staff are appropriately trained without compromising rapid study start-up, quality of training, ethical compliance, GCP, running costs.

A variety of training methods exist with different studies employing one or more different training options. On site, centre specific (Site Initiation Visit (SIV/SV)), central, multi-centre (Investigator Meeting (IM)) or 'virtual' IM training methods are often employed during start-up to enable in-depth protocol, safety, laboratory, informed consent and CRF completion guidelines and training. This ensures standardisation of study procedures across sites and that all site staff are informed of the procedures for conduct of the study.

GCP and research governance guidelines state all study personnel are 'qualified by education, training and experience'. Training should be proportionate and tailored to the specific needs of the site/study personnel. It should promote GCP but not replace formal GCP training.

Experience from setting up a large UK multi-centre RCT (Vault or Uterine prolapse surgery Evaluatioin, VUE) indicates study sites appreciate the networking and open discussion opportunities provided by a central IM, but prefer the one to one site specific training that a SIV provides, and are particularly motivated by personal study training/information packs.

This presentation will discuss essential components of study training and different training methods to promote rapid trial start up as well as feedback from site personnel exposed to different training methods.

Published: 29 November 2013

University of Aberdeen, Aberdeen, UK

() 2013 Constable et al; licensee BioMed Central Ltd. This is an Open Access article distributed under the terms of the Creative Commons Attribution License (http://creativecommons.org/licenses/by/2.0), which permits unrestricted use, distribution, and reproduction in any medium, provided the original work is properly cited.
doi:10.1186/1745-6215-14-S1-P129

Cite this article as: Constable et al:: Developing effective and efficient study specific training to enable rapid study start up. Trials 2013 14(Suppl 1):P129.

Submit your next manuscript to BioMed Central and take full advantage of:

- Convenient online submission

- Thorough peer review

- No space constraints or color figure charges

- Immediate publication on acceptance

- Inclusion in PubMed, CAS, Scopus and Google Scholar

- Research which is freely available for redistribution

\section{() Biomed Central}

